\title{
Dr. Carlos Pereira Magalhães Júnior
}

Faleceu no dia 6 de fevereiro, aos 84 anos no Hospital Israelita Albert Einstein o Dr. Carlos Pereira de Magalhães Júnior, após grave enfermidade.

Foi professor do ginásio Anglo Latino e formou-se pela Faculdade de Medicina da Universidade de São Paulo em 1944. Entrou para o Serviço de Anestesiologia do Hospital das Clínicas em 1945, onde permaneceu até 1956.

Em 1955, foi Presidente do Departamento de Anestesiologia da Associação Paulista de Medicina.

Em 1956, foi Diretor, participando ativamente da Fundação da Clínica de Anestesia de São Paulo, onde foi criado o primeiro Centro de Ensino e Treinamento em Anestesiologia da Sociedade Brasileira de Anestesiologia (CET/SBA).

Em 1959, recebeu o título de Especialista, após concurso da Sociedade Brasileira de Anestesiologia, tendo participado ativamente de Jornadas e Congressos da especialidade no Brasil e no exterior, salientando-se nas lutas pela defesa da classe em 1956 e 1966, quando da unificação dos Institutos de Previdência.

Personalidade forte e austera era, entretanto, muito cordial no trato com amigos e colegas, tendo recebido homenagem da Sociedade de Anestesiologia do Estado de São Paulo (SAESP) em maio de 1996.

Casado com Sônia Pereira de Magalhães, com quem constituiu numerosa família: oito filhos, dezoito netos e sete bisnetos.

A lembrança que todos guardam deste homem e médico dedicado, jamais será esquecida pelas suas qualidades, competência, bondade, equilíbrio, honestidade, dedicação à sua família, amigos e colegas.

Clínica de Anestesia São Paulo
We regret to make known that Dr. Carlos Pereira Magalhães Júnior passed away at 84 years of age, on February 6, 2002, after a severe disease, at Hospital Albert Einstein.

He has been a professor at Ginásio Anglo Latino and graduated in Medicine by the University of São Paulo, in 1944. He joined the Anesthesiology Department of Hospital das Clínicas in 1945, where he remained until 1956.

In 1955, Dr. Magalhães was elected President of the Department of Anesthesiology of the Medical Association of the State of São Paulo.

In 1956 he became a Director, actively participating in the foundation of the Clinic of Anesthesiology São Paulo, where the first Anesthesiology Teaching and Training Center of the Brazilian Society of Anesthesiology (CET/SBA) was created.

In 1959, Dr. Carlos Pereira Magalhães Júnior was awarded the title of Specialist, after a contest by the Brazilian Society of Anesthesiology, having actively participated in specialty Journeys and Meetings both in Brazil and abroad. He was distinguished for striving on behalf of the class in 1956 and 1966, when the Social Security System was unified.

With a strong and austere personality he was nevertheless very kind in dealing with friends and colleagues and was honored by the Society of Anesthesiology of the State of São Paulo (SAESP) in May 1996.

Dr. Magalhães was married to Sônia Pereira de Magalhães, with whom he constituted a large family: 8 children, 18 grandchildren and 7 great-grandchildren.

The memory we all have of this dedicated man and physician will neverbe forgotten for his qualities, competence, kindness, judgment, honesty and dedication to his family, friends and colleagues.

Clinic of Anesthesiology São Paulo 